\title{
Degradation of sea urchin feces in a rocky subtidal ecosystem: implications for nutrient cycling and energy flow
}

\author{
Leah K. Sauchyn*, Robert E. Scheibling \\ Biology Department, Dalhousie University, Halifax, Nova Scotia B3H 4J1, Canada
}

\begin{abstract}
During destructive grazing events in the Northwest Atlantic, sea urchins Strongylocentrotus droebachiensis consume large amounts of kelp biomass, transforming this material into feces. To determine the role of urchin fecal material in nutrient cycling and energy flow in the shallow rocky subtidal zone, we monitored the physical, chemical, and microbial degradation of urchin feces at 6 , 9, 12, and $16 \mathrm{~m}$ depth over $19 \mathrm{~d}$ at a wave-exposed site on the Atlantic coast of Nova Scotia by quantifying changes in fecal biochemical composition, pellet size, and settling velocity. We observed an exponential loss of fecal material and rapid degradation of total and labile organic matter fractions; this suggests that urchin fecal production plays an important role in local nutrient cycling and energy flow via the microbial food web. As the feces were further degraded there was a relative increase in organic carbon, nitrogen, lipid, and available energy content, and a decrease in the C:N ratio, suggesting that degraded urchin feces are an important food source for suspension- and deposit-feeding invertebrates. The settling velocity of the feces also decreased over time, likely due to a decrease in fecal pellet density. Older, less dense feces with a relatively high energy content are more likely to be suspended and transported horizontally, providing a mechanism for the export of kelp primary production to deeper, less productive waters.
\end{abstract}

KEY WORDS: Feces · Strongylocentrotus droebachiensis $\cdot$ Degradation · Biochemical composition Settling velocity $\cdot$ Microbial decomposition $\cdot$ Saccharina longicruris

\section{INTRODUCTION}

Fecal material represents a large fraction of the organic matter pool in aquatic ecosystems and plays a key role in nutrient cycling and energy flow in aquatic food webs. As compact aggregations of organic matter, feces are an important food source for the microbial community, stimulating the growth of attached and free-living bacteria and protozoa (Pomeroy \& Deibel 1980, Peduzzi \& Herndl 1986, González \& Biddanda 1990, Yoon et al. 1996, Povero et al. 2003, Thor et al. 2003). In turn, microbes accelerate rates of fecal degradation and nutrient cycling through hydrolysis of particulate organic matter (POM) (Johannes \& Satomi 1966, González \& Biddanda 1990, Fabiano et al. 1994, Urban-Rich 1999, Thor et al. 2003). Microbes also con- tribute to the labile organic matter fraction of fecal material (González \& Biddanda 1990, Fabiano et al. 1994) and increase its nutritional value through mineralization of dissolved organic matter (DOM) (González \& Biddanda 1990, Fabiano et al. 1994, Urban-Rich 1999, Povero et al. 2003) and uptake of inorganic nutrients from the water column (Wotton \& Malmqvist 2001, Povero et al. 2003). Feces are a food source for various coprophagous species, including meiofauna (Johannes \& Satomi 1966, Paffenhöfer \& Knowles 1979, Rothans \& Miller 1991) and some fish (Bailey \& Robertson 1982, Robertson 1982, Pinnegar \& Polunin 2006), as well as deposit and suspension feeders (Newell 1965, Frankenberg \& Smith 1967). Fecal pellets also serve as a vehicle for export of organic matter from pelagic and coastal waters via vertical and horizontal advective 
transport (Robison \& Bailey 1981, Madin 1982, Taghon et al. 1984, Yoon et al. 1996, Giles \& Pilditch 2004). The role of fecal production by zooplankton (Turner 2002) and fish (Bray et al. 1981, Robison \& Bailey 1981, Bailey \& Robertson 1982, Robertson 1982, Geesey et al. 1984, Rothans \& Miller 1991, Pinnegar \& Polunin 2006) in aquatic ecosystems has been extensively studied. In contrast, relatively few studies have examined the role of fecal production by macrobenthic grazers in nearshore ecosystems (Peduzzi \& Herndl 1986, Koike et al. 1987, González \& Biddanda 1990, Mills et al. 2000, Mamelona \& Pelletier 2005).

The sea urchin Strongylocentrotus droebachiensis is the dominant grazer in the shallow rocky subtidal zone of the Northwest Atlantic, where it plays a key role in determining benthic community structure (Scheibling \& Hatcher 2007). At high population densities (up to 500 ind. $\mathrm{m}^{-2}$ ), these urchins form destructive grazing fronts, driving the transition from highly productive kelp beds (mostly Saccharina longicruris and Laminaria digitata) to less productive urchin barrens dominated by crustose coralline algae (Breen \& Mann 1976, Scheibling et al. 1999, Lauzon-Guay \& Scheibling 2007a). During these destructive grazing events, the sea urchins consume a large amount of kelp biomass (Chapman \& Johnson 1990, Lauzon-Guay \& Scheibling 2007a). Estimates of kelp consumption rate per linear meter of sea urchin front range from 454 to $530 \mathrm{~g}$ dry weight $d^{-1}$ (Lauzon-Guay \& Scheibling 2007a, L. K. Sauchyn \& R. E. Scheibling unpubl. data) in fronts that can extend for $100 \mathrm{~s}$ of $\mathrm{m}$ to $\mathrm{km}$ alongshore. In a laboratory feeding experiment, we found that, on average, $20 \%$ of the mass of kelp consumed is egested as mucuscovered fecal pellets 1 to $3 \mathrm{~mm}$ in diameter (L. K. Sauchyn \& R. E. Scheibling unpubl. data). This translates into a defecation rate per linear $\mathrm{m}$ of front of 91 to $106 \mathrm{~g}$ dry weight $\mathrm{d}^{-1}$. Thus, sea urchin fecal pellets represent a significant source of detritus exported from the kelp beds during the transition to urchin barrens.

To understand the role of sea urchin fecal material in nutrient cycling and energy flow in the shallow rocky subtidal zone it is necessary to examine rates and patterns of fecal decay. Newly egested feces are subject to fragmentation and dissolution of organic matter by physical and chemical processes and microbial decomposition. These processes, in turn, influence the biochemical and physical properties of the feces (González \& Biddanda 1990, Roy \& Poulet 1990, Yoon et al. 1996, Urban-Rich 1999, Thor et al. 2003). In the present study, we examined the degradation of feces of Strongylocentrotus droebachiensis by monitoring changes in biochemical composition and size of fecal pellets in a field experiment at different depths. We also determined the settling velocity of these pellets at different stages of degradation to assess the potential for resus- pension and advective transport of fecal POM to adjacent ecosystems (e.g. deep-water sedimentary habitats). While numerous studies have addressed the role of grazing by $S$. droebachiensis in shaping algal distributions and benthic community structure in the shallow subtidal zone (Scheibling \& Hatcher 2007), only recently has the importance of grazing been addressed in terms of fecal production (Mamelona \& Pelletier 2005). The present study extends this work by examining in detail the organic composition and energetic content of sea urchin feces at various stages of degradation, and the potential for export of this material from sites of production along grazing fronts.

\section{MATERIALS AND METHODS}

Study site. The study was conducted at Splitnose Point $\left(44^{\circ} 22.609^{\prime} \mathrm{N}, 63^{\circ} 32.741^{\prime} \mathrm{W}\right)$, a headland off Ketch Harbour on the Atlantic Coast of Nova Scotia, Canada. In August 2007, a luxuriant kelp bed extended from the low intertidal to a depth of 6 to $8 \mathrm{~m}$ below chart datum and over an offshore distance of $\sim 150 \mathrm{~m}$. The kelp canopy consisted mainly of Saccharina longicruris and Laminaria digitata, with an understory turf of red algae (Chondrus crispus, Phycodrys rubens, and Ptilota serrata). A dense front of Strongylocentrotus droebachiensis was destructively grazing the kelp bed along its lower margin, creating urchin barrens dominated by crustose coralline algae (mainly Lithothamnion glaciale and Phymatolithon lenormandii) and patches of the plumose brown alga Desmarestia viridis. Sea urchins extended throughout the barrens to a depth of $35 \mathrm{~m}$ below chart datum, where the gently sloping granite ledges and crevices grade into sand. For a detailed description of the site and advance of the sea urchin front, see Lauzon-Guay \& Scheibling $(2007 a, b)$.

Experimental design. Sea urchins were collected by divers from the barrens at Splitnose Point on 13 August 2007 and immediately transferred to the laboratory. A total of 800 urchins ranging in size from 35 to $55 \mathrm{~mm}$ test diameter were placed in 16 flow-through seawater aquaria (0.6 $1 \mathrm{~min}^{-1}, 47 \mathrm{l}$ capacity). An air stone was placed in each aquarium to increase oxygenation and circulation. The average transit time for material in the gut of Strongylocentrotus droebachiensis is $2 \mathrm{~d}$ (Lawrence \& Klinger 2001). Therefore, to ensure that the feces egested came from the laboratory diet, all sea urchins were fed ad libitum for $1 \mathrm{wk}$ with fresh Saccharina longicruris, cleaned of epiphytes and epizoonts.

On 19 August 2007, all kelp and fecal material was removed from the aquaria by gentle suction and $150 \mathrm{~g}$ of fresh and clean Saccharina longicruris was added to each aquarium ( $3 \mathrm{~g}$ sea $\operatorname{urchin}^{-1} \mathrm{~d}^{-1}$ ). After $24 \mathrm{~h}$, the 
newly produced feces were collected and pooled across all aquaria. Samples were collected to determine the initial (Day 0) biochemical composition, pellet size distribution, and settling velocities; $2 \mathrm{~g}$ of the pooled fecal material was then allocated to each of 112 screw-top Ziploc ${ }^{\circledR}$ plastic containers $(500 \mathrm{ml})$, perforated with 22 holes (1 $\mathrm{cm}$ diameter) that were covered with $63 \mu \mathrm{m}$ Nitex ${ }^{\circledR}$ mesh. This mesh size allowed exchange of bacteria and most protozoa from the surrounding seawater, but excluded larger metazoans. Each container was filled with $0.2 \mu \mathrm{m}$ filtered seawater and placed in a sealed Ziploc ${ }^{\circledR}$ bag. Containers were deployed in the field within 1 to $2 \mathrm{~h}$.

At Splitnose Point, the containers were removed from the Ziploc ${ }^{\circledR}$ bags underwater and attached to bases anchored to the substrate with marine epoxy (ZSpar A-788 Splash Zone Compound) at 6, 9, 12, and $16 \mathrm{~m}$ depth (below chart datum) by divers (28 containers per depth). Temperature was recorded at each depth every $30 \mathrm{~min}$ with anchored temperature loggers (StowAway TidbiT Temp Logger, Onset Computer Corporation). Wind-driven upwelling events resulted in relatively low temperatures across all depths at the beginning and end of the experiment (Fig. 1); however, throughout the experiment, water temperature was highest at $6 \mathrm{~m}$, decreasing with depth to $16 \mathrm{~m}$ (Fig. 1). A subset of containers was collected from each depth $3,7,12$, and $19 \mathrm{~d}$ after deployment to determine the biochemical composition, size distribution, and settling velocities of the remaining feces.

Biochemical composition. Samples of fecal material collected before and after deployment were filtered onto pre-combusted GF/F filters $(0.7 \mu \mathrm{m})$. Feces were transferred to acid-washed vials with parafilm-lined caps, immediately frozen at $-80^{\circ} \mathrm{C}$, and freeze-dried for $72 \mathrm{~h}$. Freeze-dried feces were homogenized and analyzed for organic carbon, nitrogen, protein, lipid,

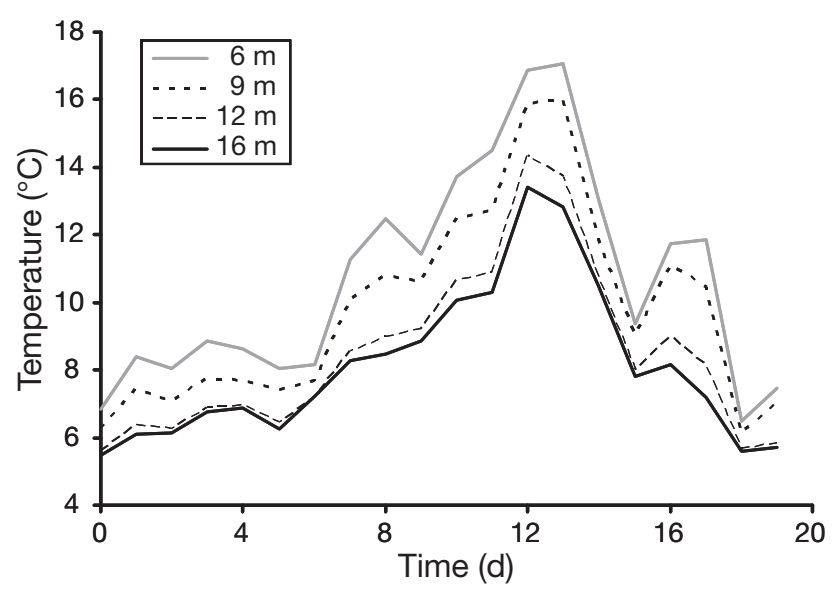

Fig. 1. Mean daily temperature at 4 depths over the $19 \mathrm{~d}$ degradation experiment at Splitnose Point and carbohydrate content. The biochemical content was expressed as a percentage of the remaining sample dry weight.

Organic carbon and nitrogen contents were estimated by flash combustion in a Perkin Elmer 2400 $\mathrm{CHN}$ analyzer. Protein was extracted in $1 \mathrm{~N} \mathrm{NaOH}$ and the concentration was estimated by the Lowry method (Lowry et al. 1951). Bovine serum albumin was used as a standard and the optical density was measured at $600 \mathrm{~nm}$. Lipid was extracted in a 2:1 chloroform:methanol solution (v/v) and the concentration was estimated using the gravimetric method (Folch et al. 1957). Carbohydrate was extracted in 5\% trichloroacetic acid and the concentration was estimated using the phenol-sulfuric acid method (Dubois et al. 1956). Glucose was used as a standard and the optical density was measured at $492 \mathrm{~nm}$.

Size distribution and settling velocity. Samples of fecal material collected before and after deployment were wet-sieved through a stacked series of 636, 363, 150, and $63 \mu \mathrm{m}$ Nitex ${ }^{\circledR}$ mesh. During sieving, fecal pellets were gently rinsed with seawater to prevent compaction while minimizing particle disaggregation. The size distribution of fecal material from each sample was estimated by determining the wet weight of each size fraction $(>636,636-363,363-150$, and 150-63 $\mu \mathrm{m})$. Settling velocities of particles in the 3 largest size fractions were estimated at $23^{\circ} \mathrm{C}$ (room temperature) and $4^{\circ} \mathrm{C}$ (cold room) within $24 \mathrm{~h}$ of collection. These temperatures were chosen to approximate maximum $\left(18.2^{\circ} \mathrm{C}\right)$ and minimum $\left(3.9^{\circ} \mathrm{C}\right)$ temperatures encountered in the field during the experiment. Settling velocities were not estimated for the smallest size fraction (150-63 $\mu \mathrm{m})$ because the particles were too small to resolve using video.

Settling velocity was estimated by gently releasing the fecal material just below the water surface in a $10 \times$ $10 \times 60 \mathrm{~cm}$ settling chamber. Particles were recorded on digital video (SONY DCR-VX2000 MiniDV Handy$\operatorname{cam}^{\circledR}$ ) while sinking between 20 and $40 \mathrm{~cm}$ below the water surface. The video was downloaded and analyzed using iMovie (v.3.0.3). Settling velocity was calculated as the distance traveled, determined by a scale attached to the outer wall of the settling chamber, over the time passed on the video $\left(\mathrm{cm} \mathrm{s}^{-1}\right)$. The settling velocity was estimated for 2 to 10 particles in each size fraction from each sample. The mean settling velocity for each size fraction was calculated based on the settling velocities of 2 samples collected from each depth at each sampling interval.

Statistical analysis. The effect of time and depth on the loss of fecal material, expressed as a proportion of the initial sample dry weight, from Days 3 to 19, was examined using ANOVA, followed by Tukey's HSD $(\alpha=0.05)$ tests. A 1 -sample $t$-test was used to compare 
the proportion of material remaining at Day 3 to an expected mean of 1 (proportion at Day 0).

Changes in organic carbon and nitrogen content over time and across depths were examined using multivariate ANOVA (MANOVA). The data met the assumption of homogeneity of variance (Levene's test, $\alpha=0.05$ ) but violated the assumption of homogeneity of covariance matrices (Box's $M$-test, $\alpha=0.05$ ). However, given moderate heterogeneity and a sample size ratio of approximately 2 , the Type 1 error rate remains $\leq 0.05$ if we apply $\alpha=0.01$ (Hakstian et al. 1979). The data also violated the assumption of multivariate normality (Henze-Zirkler test, $\alpha=0.05$ ); however, Wilks' $\lambda$ is robust to deviations from normality (Stevens 1986). A significant multivariate result was followed by Tukey's HSD tests to determine which variables accounted for any observed difference across time and depth (Stevens 1986).

Changes in protein, lipid, and carbohydrate content over time and across depths were also examined using MANOVA. These data met the assumption of homogeneity of variance-covariance matrices, but violated the assumption of multivariate normality. A significant multivariate result was followed by Bonferroniadjusted Hotelling's $T$-squared tests $(\alpha=0.15)$ to determine which days and/or depths differed based on the set of variables, and Tukey's HSD tests to determine which variables accounted for the group differences. The available energy content ( $\mathrm{kJ} \mathrm{g}^{-1}$ dry weight) of the fecal material was calculated using energy equivalents for protein $\left(23.64 \mathrm{~kJ} \mathrm{~g}^{-1}\right)$, lipid $\left(39.54 \mathrm{~kJ} \mathrm{~g}^{-1}\right)$, and carbohydrate (16.74 $\mathrm{kJ} \mathrm{g}^{-1}$ ) (Brody 1945). The effect of time and depth on energy content was examined using ANOVA followed by Tukey's HSD tests.

The amount of fecal material in each size fraction was expressed as a proportion of the initial sample wet weight. Throughout the study, most of the fecal material was > $636 \mu \mathrm{m}$ (mean \pm SD: $85 \pm 13 \%$ wet weight) and only this size fraction was analyzed statistically. Changes in the proportion of fecal material in the largest size fraction over time and across depths was examined using ANOVA, followed by Tukey's HSD tests. The data were arcsine square-root transformed prior to analysis to meet the assumptions of normality (Shapiro-Wilks test, $\alpha=0.05$ ) and homogeneity of variance (Levene's test, $\alpha=0.05$ ).

The effects of time, size $(>636,636-363$, and $363-150 \mu \mathrm{m})$, temperature $\left(4\right.$ and $\left.23^{\circ} \mathrm{C}\right)$, and depth on settling rate were examined using ANOVA followed by Tukey's HSD tests. Data were $\log _{10}$-transformed prior to analysis to meet the assumption of homogeneity of variance (Levene's test, $\alpha=0.05$ ). The transformed data violated the assumption of normality (Shapiro-Wilks test, $\alpha=0.05$ ); however, the F-statistic is robust to deviations from normality (Zar 1999).

\section{RESULTS}

\section{Biochemical composition}

The proportion of feces remaining during degradation decreased significantly from Days 0 to $3\left(t_{12}=\right.$ $-14.1, \mathrm{p}<0.001)$ and over the remainder of the experiment $\left(F_{3,33}=7.22, \mathrm{p}=0.001\right)$. There was no effect of depth $\left(F_{3,33}=0.323, \mathrm{p}=0.809\right)$ or interaction between time and depth $\left(F_{9,33}=0.882, \mathrm{p}=0.551\right)$ on the loss of fecal material. Non-linear regression of the proportion of initial weight $(W)$ against time $(t)$ showed an exponential loss of fecal material (Fig. 2). This model was compared to simpler and more complicated models of exponential decay using Akaike's information criterion for small sample size $\left(\mathrm{AIC}_{\mathrm{c}}\right)$. This model had the lowest $\mathrm{AIC}_{\mathrm{C}}$ value $\left(\mathrm{AIC}_{\mathrm{cmin}}\right)$ and the $\mathrm{AIC}_{\mathrm{c}}$ differences $\left(\Delta_{\mathrm{i}}=\right.$ $\mathrm{AIC}_{\mathrm{ci}}-\mathrm{AIC}_{\mathrm{cmin}}$ ) of all other models tested were $>2$, providing support for the selected model (Burnham \& Anderson 2002).

The organic carbon and nitrogen contents of the fecal material also varied significantly $(\alpha=0.01)$ over time $\left(\lambda=0.191, F_{8,112}=18.0, \mathrm{p}<0.001\right)$ but not across depths $\left(\lambda=0.924, F_{6,112}=0.752, p=0.609\right)$, and there was no significant interaction between time and depth $\left(\lambda=0.788, F_{24,112}=0.589, p=0.932\right)$. Carbon and nitrogen contents decreased rapidly within the first 3 d (Fig. 3). Nitrogen content decreased more rapidly than carbon content, resulting in a peak of 25.4 in the C:N ratio at Day 3 (Fig. 3). Although carbon and nitrogen contents remained significantly lower than the initial value (Day 0) throughout the course of the experiment, there was a significant increase in carbon from Day 12 to 19, and in nitrogen from Day 3 to 19

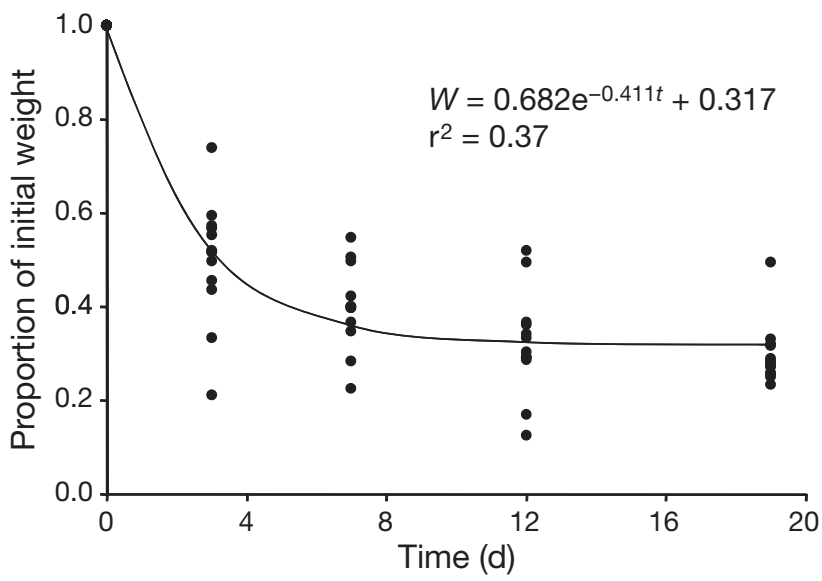

Fig. 2. Strongylocentrotus droebachiensis. Change in proportion of initial dry weight $(W)$ of sea urchin feces over time $(t)$ during the $19 \mathrm{~d}$ degradation experiment at Splitnose Point. Data are for 10 to 28 samples pooled across 4 experimental depths $(6,9,12,16 \mathrm{~m})$, collected at each sampling date $(0,3$, $7,12,19 \mathrm{~d})$ 

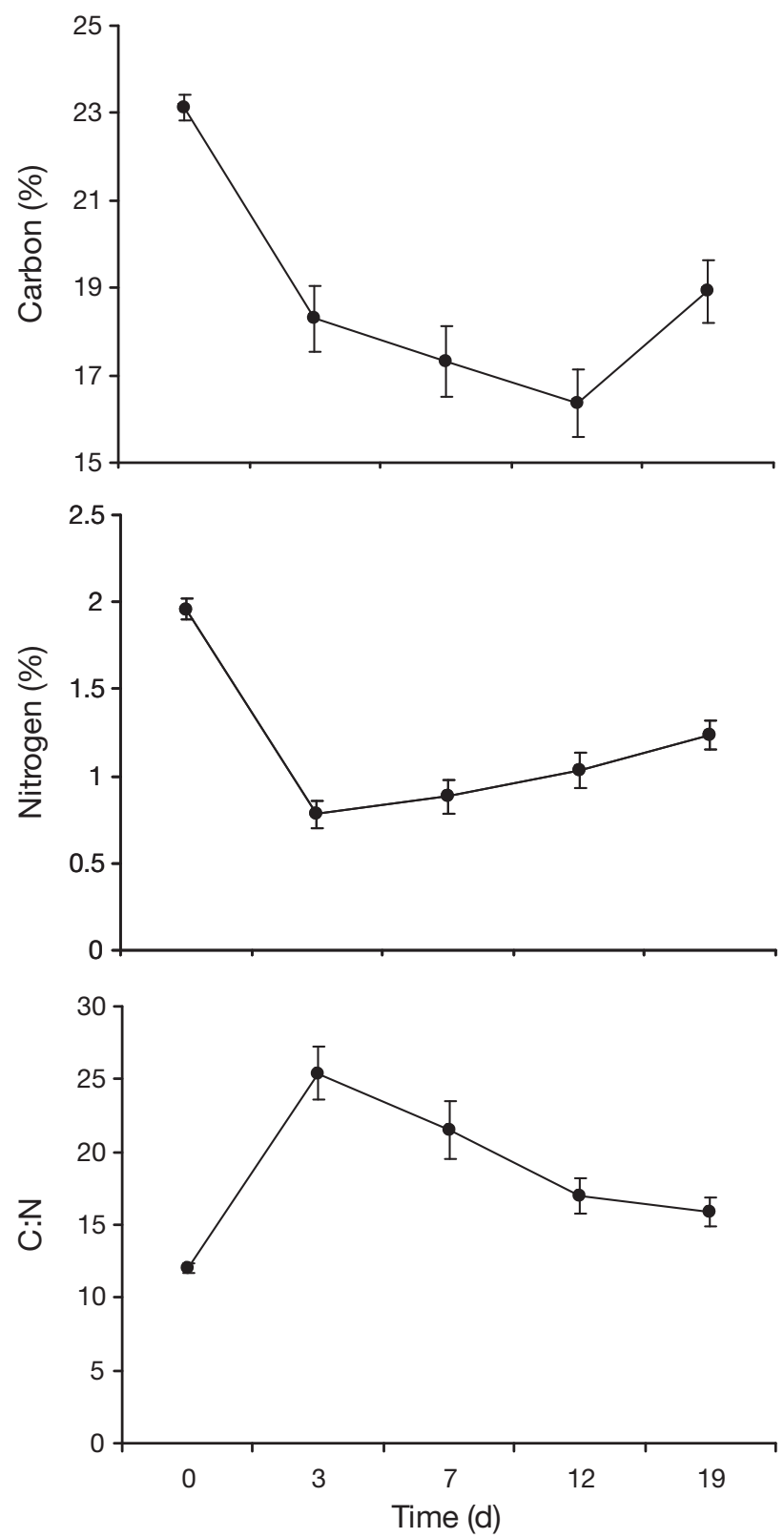

Fig. 3. Strongylocentrotus droebachiensis. Organic carbon and nitrogen content and $\mathrm{C}: \mathrm{N}$ ratio of sea urchin feces over the $19 \mathrm{~d}$ degradation experiment at Splitnose Point. Data are mean \pm SE of 10 to 28 samples pooled across 4 experimental depths $(6,9,12,16 \mathrm{~m})$

(Tukey's HSD tests). Again, the increase in nitrogen was greater than that in carbon, resulting in a decrease in the C:N ratio from Day 3 to 19 (25.4 to 15.9) (Fig. 3).

The labile organic matter content (protein, lipid, and carbohydrate) composed, on average, $50 \pm 3 \%( \pm \mathrm{SE})$ of the total fecal organic carbon at the start of the experiment. There were significant effects of time $(\lambda=0.237$, $\left.F_{12,145}=8.80, \mathrm{p}<0.001\right)$, depth $\left(\lambda=0.739, F_{9,134}=1.97\right.$, $\mathrm{p}=0.047$, and the interaction between time and depth
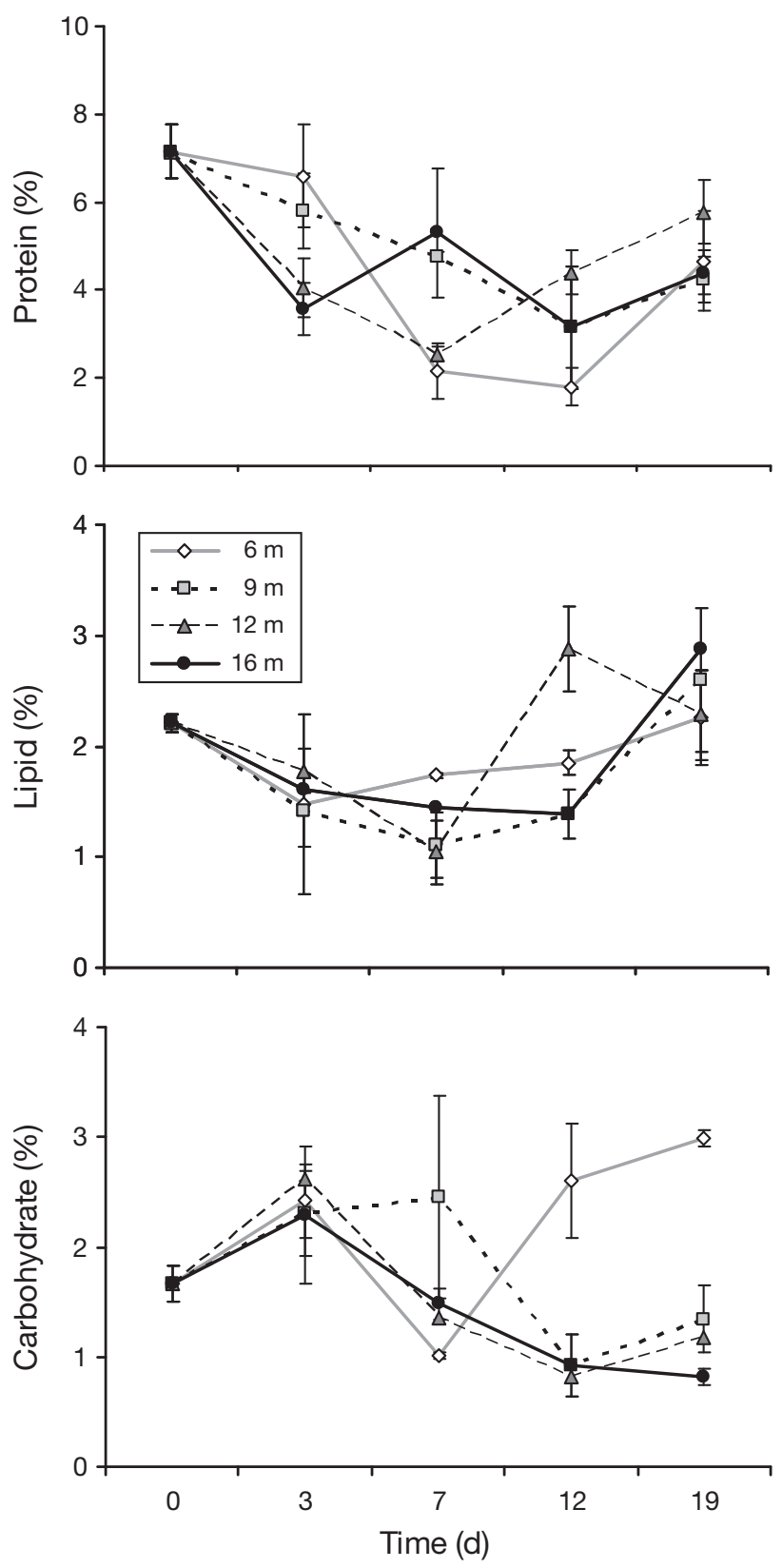

Fig. 4. Strongylocentrotus droebachiensis. Protein, lipid, and carbohydrate content of sea urchin feces across 4 depths over the $19 \mathrm{~d}$ degradation experiment at Splitnose Point. Data are mean \pm SE of 2 to 7 samples at each depth

$\left(\lambda=0.280, F_{36,163}=2.44, \mathrm{p}<0.001\right)$ on labile organic matter content. Labile organic matter content decreased from the start of the experiment to Day 7, followed by a significant relative increase from Day 7 to 19 (Bonferroni-adjusted Hotelling's T-squared tests). Protein, lipid, and carbohydrate contents combined accounted for this observed change over time (Tukey's HSD tests). Protein content (averaged across depth) decreased significantly from 7.2 to $4.9 \%$ during the experiment (Days 0 to 19) (Fig. 4). Lipid content 
decreased significantly from Day 0 to 7 , then increased to Day 19, such that there was no significant difference between lipid content (averaged across depth) at the beginning $(2.2 \%)$ and end $(2.3 \%)$ of the experiment (Fig. 4). Carbohydrate content at 9, 12, and $16 \mathrm{~m}$ decreased significantly from 2.4 to $1.2 \%$ from Day 3 to 19 (Fig. 4). The different patterns of change in protein content, through time and across depths, and the increase in carbohydrate content at $6 \mathrm{~m}$ from Day 7 to 19 accounted for the significant interaction between time and depth on labile organic matter content (Tukey's HSD tests). Tukey's HSD tests showed that carbohydrate content (averaged over time) was greater at $6 \mathrm{~m}$ than at 12 or $16 \mathrm{~m}$, accounting for the marginally significant depth effect on labile organic matter content $(\mathrm{p}=0.047)$.

The available energy content, calculated based on energy equivalents for protein, lipid, and carbohydrate, reflected changes in the labile organic matter content (Fig. 5). Energy content varied significantly over time $\left(F_{4,57}=17.4, \mathrm{p}<0.001\right)$ but not across depth $\left(F_{3,57}=0.020, p=0.959\right)$. Energy content (averaged across depth) decreased significantly from 2.84 to $1.66 \mathrm{~kJ} \mathrm{~g}^{-1}$ (dry weight) between Days 0 and 7, and then increased again to $2.33 \mathrm{~kJ} \mathrm{~g}^{-1}$ by Day 19 (Tukey's HSD tests). The interaction between time and depth was significant $\left(F_{12,57}=0.391, \mathrm{p}=0.038\right)$, reflecting the greater energy content at 9 and $16 \mathrm{~m}$ in the middle of the experiment compared to at 6 and $12 \mathrm{~m}$ (Fig. 5).

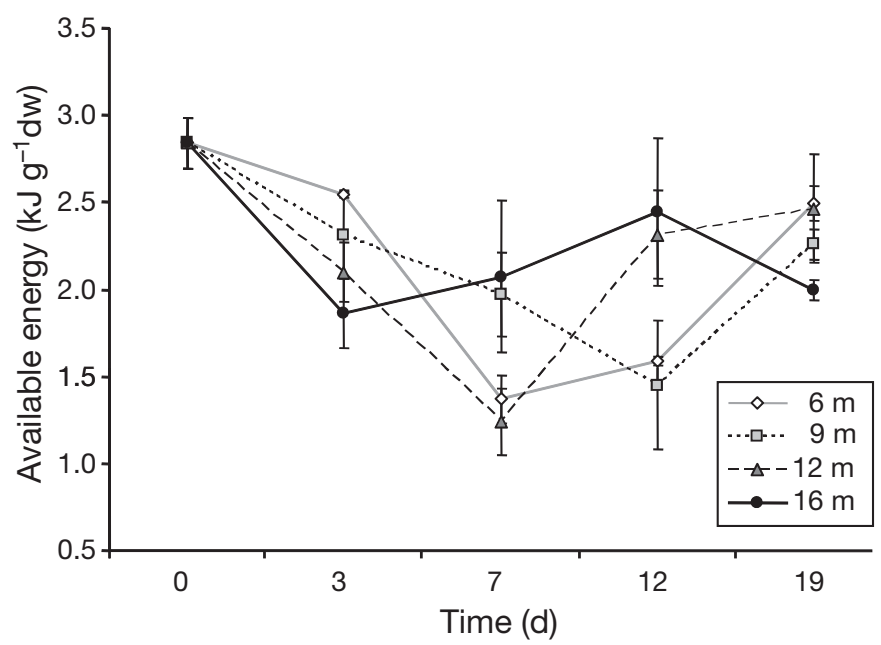

Fig. 5. Strongylocentrotus droebachiensis. Available energy content of sea urchin feces across 4 depths over the $19 \mathrm{~d}$ degradation experiment at Splitnose Point. Data are mean \pm SE of 2 to 7 samples at each depth. dw = dry weight

\section{Size distribution and settling velocity}

Throughout the experiment, the majority of fecal material ( $85 \%$ wet weight) was $>636 \mu \mathrm{m}$. Within this size fraction there was a significant loss of material $\left(F_{4,20}=0.689, \mathrm{p}<0.001\right)$, from 88 to $20 \%$ of the initial sample weight between Days 0 and 19, but no effect of depth $\left(F_{3,20}=0.223, \mathrm{p}=0.879\right)$ or interaction between time and depth $\left(F_{12,20}=0.788, \mathrm{p}=0.657\right)$. There was little change in the smaller size fractions throughout the experiment that, combined, accounted for $<10 \%$ of the initial weight between Days 3 and 19 (Fig. 6).

Particle settling velocity varied over time, among size fractions, and between the 2 settling temperatures. The difference in settling velocity among the 3 size fractions accounted for most of the variance in the model $\left(\eta^{2}=\right.$ 0.621) (Table 1). There was no significant effect of depth or any interaction including depth, and so depth was removed from the model. There were significant 2way interactions of size and temperature with time, and a significant 3-way interaction between time, size and temperature (Table 1). Tukey's HSD tests showed that settling velocity was greater for larger fecal pellets (averaged over time and temperature) and greater at 23 than $4{ }^{\circ} \mathrm{C}$ (averaged over time and size) (Fig. 7). The settling velocity (averaged over temperature) decreased significantly within each size fraction over the course of the experiment (Fig. 7); however, the pattern of decrease depended on both size and temperature, resulting in the significant 3-way interaction.

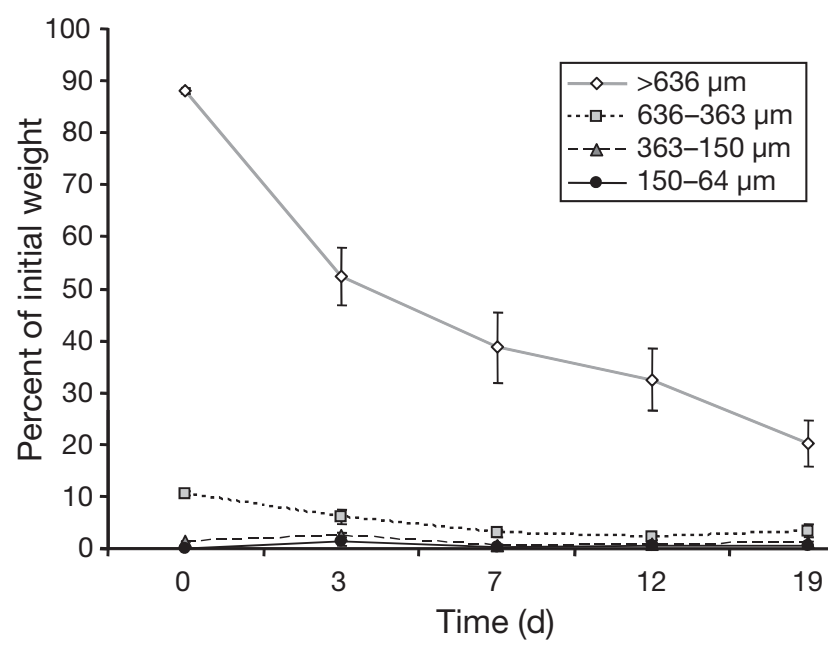

Fig. 6. Strongylocentrotus droebachiensis. Change in percentage of initial wet weight of sea urchin feces in 4 size fractions over the $19 \mathrm{~d}$ degradation experiment at Splitnose Point. Data are mean \pm SE of 8 samples pooled across 4 experimental depths $(6,9,12,16 \mathrm{~m})$ 
Table 1. Strongylocentrotus droebachiensis. ANOVA of the effect of degradation time, pellet size, and settling temperature on the settling velocity of sea urchin feces. $\eta^{2}$ is the variance component for each term in the model

\begin{tabular}{|lcrrrr|}
\hline Source of variation & df & MS & $F$ & $\eta^{2}$ & $\mathrm{p}$ \\
\hline Time & 4 & 2.453 & 26.17 & 0.104 & $<0.001$ \\
Size & 2 & 29.162 & 311.15 & 0.621 & $<0.001$ \\
Temperature & 1 & 1.998 & 21.32 & 0.021 & $<0.001$ \\
Time $\times$ Size & 8 & 0.482 & 5.14 & 0.041 & $<0.001$ \\
Time $\times$ Temperature & 4 & 0.781 & 8.34 & 0.033 & $<0.001$ \\
Size $\times$ Temperature & 2 & 0.101 & 1.08 & 0.002 & 0.342 \\
Time $\times$ Size $\times$ Temperature & 8 & 0.315 & 3.36 & 0.027 & 0.001 \\
Residual & 150 & 0.094 & & & \\
\hline
\end{tabular}

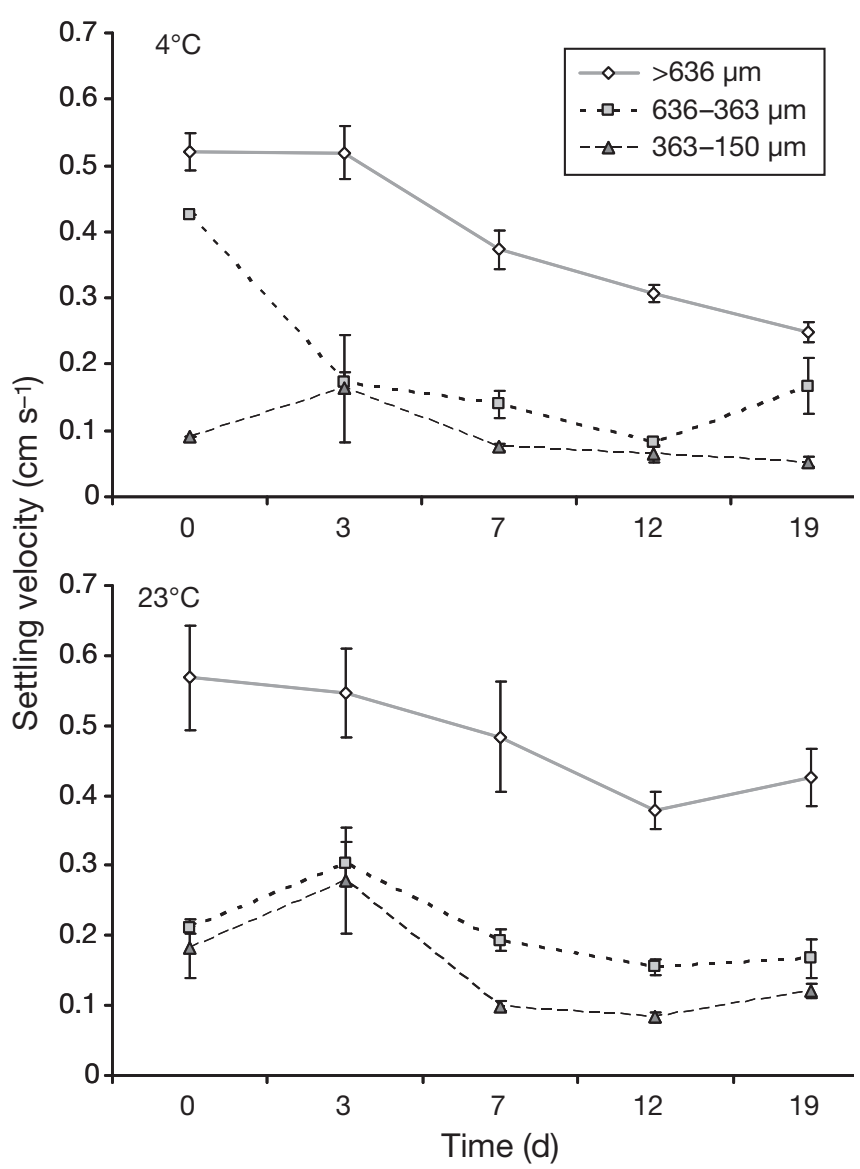

Fig. 7. Strongylocentrotus droebachiensis. Settling velocity of sea urchin feces at 4 and $23^{\circ} \mathrm{C}$ in the 3 largest size fractions over the $19 \mathrm{~d}$ degradation experiment at Splitnose Point. Data are means $\pm \mathrm{SE}$ for 2 to 8 samples in each size fraction

\section{DISCUSSION}

We observed an exponential loss of fecal dry weight during our 19 d experiment, with a fecal half-life of $4.13 \mathrm{~d}$. This is similar to the half-life of decaying isopod (4 d, González \& Biddanda 1990) and salp (3.4 d, Yoon et al. 1996) fecal pellets. Differences in the physical and chemical environment, microbial community, and fecal pellet size and composition may account for the slight discrepancy in decay rates between our field experiment and other laboratory studies (Turner 1979, Roy \& Poulet 1990, Thor et al. 2003). Dissolution of DOM and microbial activity probably accounted for the sharp decrease in total and labile organic matter that we observed within the first week after egestion. Studies of zooplankton fecal pellets have shown a rapid initial loss of DOM from the feces immediately after egestion (Noji et al. 1999, Urban-Rich 1999, Møller et al. 2003, Thor et al. 2003). The passive leakage of DOM results from the steep concentration gradient between the feces and surrounding water (Jumars et al. 1989). This may be particularly pronounced for sea urchin feces, which lack a peritrophic membrane that slows diffusion of DOM (Lee \& Fisher 1992). Leakage of DOM also promotes rapid colonization of feces by bacteria (Povero et al. 2003, Thor et al. 2003). The attached bacteria decompose fecal organic matter through hydrolysis of POM and mineralization of DOM (Jacobsen \& Azam 1984, Pomeroy et al. 1984, Peduzzi \& Herndl 1986, Thor et al. 2003). High rates of detachment by the particle-associated bacteria and uptake of DOM by free-living bacteria also contribute to the loss of organic matter from fecal aggregates (pellet and attached microbes) (Jacobsen \& Azam 1984, Peduzzi \& Herndl 1986, Kiørboe et al. 2003, Tang et al. 2006). We observed the greatest decrease in fecal mass and organic carbon and nitrogen content within $3 \mathrm{~d}$, which is consistent with the temporal peak in microbial activity ( 1 to $4 \mathrm{~d}$ post egestion) for feces of various aquatic animals (Jacobsen \& Azam 1984, Peduzzi \& Herndl 1986, Yoon et al. 1996, Kiørboe et al. 2003, Tang et al. 2006). The rapid dissolution of DOM and bacterial hydrolysis of POM from the large quantity of feces egested (approx. $100 \mathrm{~g} \mathrm{~m}^{-1}$ front $\mathrm{d}^{-1}$ ) suggests that sea urchin fecal production could play an important role in local nutrient cycling within the shallow rocky subtidal zone.

Although all measures of total and labile organic matter decreased initially, the patterns of decrease differed among the components. Nitrogen decreased more rapidly than organic carbon, resulting in a peak C:N ratio of 25.4 on Day 3. González \& Biddanda (1990) observed a similar decline in carbon and nitrogen in isopod fecal pellets, with a peak C:N ratio of 17 after $4 \mathrm{~d}$. They also observed an increase in carbon and nitrogen within $12 \mathrm{~h}$ after egestion due to bacterial colonization. Because we only began sampling sea urchin feces $24 \mathrm{~h}$ after egestion, we may have missed this ini- 
tial increase in bacterial carbon and nitrogen. Marine bacterial assemblages, on average, have C:N ratios ranging from 5 to 7 (Fukuda et al. 1998), much lower than that of fresh sea urchin feces (12.0). Therefore, to utilize fecal organic matter, bacteria must take up proportionally more nitrogen than organic carbon, accounting for the greater decrease in nitrogen compared to carbon. We also observed that protein and lipid contents decreased within the first $3 \mathrm{~d}$, while carbohydrate content only decreased after Day 3, suggesting preferential utilization by bacteria of protein and lipid. By measuring bacterial protease and glucosidase production, Grenz et al. (1990) and Grossart \& Ploug (2001) found evidence of preferential and more rapid utilization of protein compared to carbohydrate by attached bacteria on mussel feces/pseudofeces and marine diatom aggregates, respectively.

The initial decrease in total and labile organic matter content was followed by a relative increase in fecal organic carbon, nitrogen, lipid, and available energy content and a decrease in the $\mathrm{C}: \mathrm{N}$ ratio by the end of our experiment. Fecal enrichment may have occurred through a combination of continued microbial colonization, growth, mineralization, and uptake of dissolved inorganic nitrogen from the surrounding water column. Protozoans, such as flagellates and ciliates, colonize feces soon after bacteria, and their grazing can stimulate bacterial population growth, hydrolysis, and mineralization (Johannes 1965, Jacobsen \& Azam 1984, Pomeroy et al. 1984, Biddanda \& Pomeroy 1988, Tang et al. 2006). Protozoans also remineralize DOM released by particle-associated bacteria, contributing to the enrichment of fecal aggregates (Pomeroy et al. 1984, Biddanda \& Pomeroy 1988, Grossart \& Ploug 2001). Also, as the labile nitrogen in the feces is used up, bacteria must actively take up dissolved nitrogen (nitrate or ammonia) from the surrounding water to remineralize DOM, increasing the nitrogen content and decreasing the C:N ratio (González \& Biddanda 1990, Wotton \& Malmqvist 2001, Povero et al. 2003). The increase in available energy content and the decrease in the $\mathrm{C}: \mathrm{N}$ ratio of the feces due to microbial activity suggest that the degraded feces may be an important food source for suspension feeders (e.g. the horse mussel Modiolus modiolus) in the rocky subtidal zone, and for deposit feeders such as sea cucumbers and polychaetes in adjacent sedimentary habitats.

We also observed different patterns of change in protein, carbohydrate, and available energy content across the 4 depths over the course of the experiment. This may be due to differences in the physical environment (temperature, wave action, irradiation) and microbial assemblage at each depth (Turner 1979, Roy \& Poulet 1990, Lee \& Fisher 1992). In particular, we observed a more prolonged and greater decrease in protein and an increase in carbohydrate at $6 \mathrm{~m}$ depth. Water temperature was consistently highest at this depth, which may have stimulated increased microbial activity. Roy \& Poulet (1990) found that the carbon loss rate from copepod fecal pellets increased from 1.5 to $2.5 \mu \mathrm{g} \mathrm{C} \mathrm{mg}^{-1}$ pellet $\mathrm{d}^{-1}$ between 5 and $15^{\circ} \mathrm{C}$.

Processes of physical, chemical, and microbial degradation also change the physical properties of fecal pellets. We observed a decrease in settling velocity of fecal pellets over time in each size fraction. The settling velocity of feces depends on seawater density and viscosity and the size, density, shape, and smoothness (surface texture) of the pellets (Dietrich 1982). At a given temperature and salinity, seawater density and viscosity are constant. If we assume that the fecal pellets maintained a similar shape and smoothness, then the decrease in settling velocity was due to a decrease in pellet size and/or density. We did not observe a transfer of material from the largest to smaller size fractions during the experiment (Fig. 6). This suggests that the fecal pellets were not degraded into smaller sizes, but that the material lost from the feces was $<63 \mu \mathrm{m}$ in diameter (the mesh size of the containers and the lower limit of the smallest size fraction sampled).

If the fecal pellets lost mass without markedly decreasing in size, then a decrease in density, rather than a decrease in size, may better explain the observed decrease in settling velocity. A number of studies have suggested a decrease in density during fecal pellet degradation. González \& Biddanda (1990) found that isopod fecal pellets lost two-thirds of their initial dry weight after $16 \mathrm{~d}$, while remaining unchanged in appearance. Yoon et al. (1996) observed a greater decrease in dry weight $(89.3 \%)$ than in size $(40 \%)$ of de-

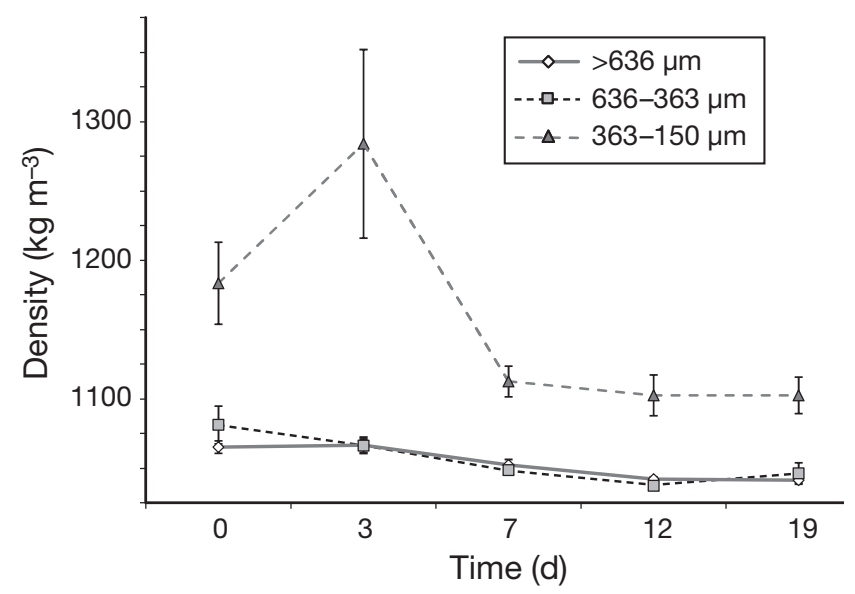

Fig. 8. Strongylocentrotus droebachiensis. Density of sea urchin feces averaged over the 2 settling temperatures in the 3 largest size fractions over the $19 \mathrm{~d}$ degradation experiment at Splitnose Point. Data are mean \pm SE for 4 to 16 samples in each size fraction 
caying salp fecal pellets over $10 \mathrm{~d}$. If we assume a constant fecal pellet size (lower limit of the 3 largest size fractions: 636, 363, and $150 \mu \mathrm{m})$, a Corey shape factor of 0.8 (L. K. Sauchyn \& R. E. Scheibling unpubl. data), and a Powers Index of 3.5 (a measure of smoothness typical of natural particles; Dietrich 1982), we observe a decrease in pellet density over time for each size fraction (Fig. 8). Recently egested fecal pellets of sea urchins feeding on kelp are transported by wave action and can be deposited at depths of 30 to $50 \mathrm{~m}$ (L. K. Sauchyn \& R. E. Scheibling unpubl. data), beyond the lower limits of kelp beds. As the pellets degrade and become less dense, they are likely to be transported to even deeper, less productive waters.

In summary, dissolution of DOM and microbial decomposition led to an exponential decrease in fecal material and rapid loss of total and labile organic matter observed during our 19 d field experiment. Although we did not consider the role of metazoans in sea urchin fecal degradation, it is unlikely they would have contributed significantly to the loss rate, given the rapidity of microbial decomposition (González \& Biddanda 1990). Rapid dissolution of DOM and evidence of intense microbial activity suggest that sea urchin fecal production plays an important role in local nutrient cycling and energy flow via the microbial food web. The relative increase in organic carbon, nitrogen, lipid, and available energy content and the decrease in the C:N ratio of the pellets, observed during our experiment, suggests that degraded feces are a valuable food resource for suspension- and deposit-feeding invertebrates. With an estimated $20 \%$ of kelp biomass consumed by sea urchins entering detrital pathways (L. K. Sauchyn \& R. E. Scheibling unpubl. data), fecal production during destructive grazing events likely constitutes an important and underappreciated component of ecosystem dynamics in the rocky subtidal zone and adjacent sedimentary habitats.

Acknowledgements. We thank J. Lindley, J. S. Lauzon-Guay, D. Lyons, M. Saunders, S. Clemente, and A. Pinder for assistance in the field, J. Jones for assistance in the laboratory, and P. Hill for advice on estimating particle density. J. S. LauzonGuay and 3 anonymous reviewers provided helpful comments on an early draft of the manuscript. This research was funded by a Discovery Grant from the Natural Sciences and Engineering Research Council of Canada (NSERC) to R.E.S. L.K.S. was supported by a Canada Graduate Scholarship (NSERC).

\section{LITERATURE CITED}

Bailey TG, Robertson DR (1982) Organic and caloric levels of fish feces relative to its consumption by coprophagous reef fishes. Mar Biol 69:45-50

Biddanda BA, Pomeroy LR (1988) Microbial aggregation and degradation of phytoplankton-derived detritus in sea- water. I. Microbial succession. Mar Ecol Prog Ser 42: 79-88 Bray RN, Miller AC, Geesey GG (1981) The fish connection: a trophic link between planktonic and rocky reef communities. Science 214:204-205

Breen PA, Mann KH (1976) Destructive grazing of kelp by sea urchins in eastern Canada. J Fish Res Board Can 33: 1278-1283

Brody S (1945) Bioenergetics and growth. Reinhold Publishing, New York

Burnham KP, Anderson DR (2002) Model selection and multimodel inference: a practical information-theoretic approach, 2nd edn. Springer, New York

Chapman ARO, Johnson CR (1990) Disturbance and organization of macroalgal assemblages in the Northwest Atlantic. Hydrobiologia 192:77-121

> Dietrich WE (1982) Settling velocity of natural particles. Water Resour Res 18:1615-1626

Dubois M, Gilies KA, Hamilton JK, Rebers PA, Smith F (1956) Colorimetric methods for determination of sugars and related substances. Anal Chem 28:350-356

Fabiano M, Danovaro R, Olivari E, Misic C (1994) Decomposition of fecal matter and somatic tissue of Mytilus galloprovincialis: changes in organic matter composition and microbial succession. Mar Biol 119:375-384

Folch J, Lees M, Stanley GHS (1957) A simple method for the isolation and purification of total lipids from animal tissues. J Biol Chem 226:497-509

Frankenberg D, Smith KL (1967) Coprophagy in marine animals. Limnol Oceanogr 12:443-450

Fukuda R, Ogawa H, Nagata T, Koike I (1998) Direct determination of carbon and nitrogen contents of natural bacterial assemblages in marine environments. Appl Environ Microbiol 64:3352-3358

Geesey GG, Alexander GV, Bray RN, Miller AC (1984) Fish fecal pellets are a source of minerals for inshore reef communities. Mar Ecol Prog Ser 15:19-25

Giles H, Pilditch CA (2004) Effects of diet on sinking rates and erosion thresholds of mussel Perna canaliculus biodeposits. Mar Ecol Prog Ser 282:205-219

González H, Biddanda B (1990) Microbial transformation of metazoan (Idotea granulosa) feces. Mar Biol 106:285-295

Grenz C, Hermin MN, Baudinet D, Daumas R (1990) In situ biochemical and bacterial variation of sediments enriched with mussel biodeposits. Hydrobiologia 207:153-160

Grossart HP, Ploug H (2001) Microbial degradation of organic carbon and nitrogen on diatom aggregates. Limnol Oceanogr 46:267-277

> Hakstian AR, Roed JC, Lind JC (1979) Two sample $\mathrm{T}^{2}$ procedures and the assumption of homogeneous covariance matrices. Psychol Bull 86:1255-1263

Jacobsen TR, Azam F (1984) Role of bacteria in copepod fecal pellet decomposition: colonization, growth-rates and mineralization. Bull Mar Sci 35:495-502

Johannes RE (1965) Influence of marine protozoa on nutrient regeneration. Limnol Oceanogr 10:434-442

Johannes RE, Satomi M (1966) Composition and nutritive value of fecal pellets of a marine crustacean. Limnol Oceanogr 11:191-197

> Jumars PA, Penry DL, Baross JA, Perry MJ, Frost BW (1989) Closing the microbial loop: dissolved carbon pathway to heterotrophic bacteria from incomplete ingestion, digestion and absorption in animals. Deep-Sea Res A 36: 483-495

Kiørboe T, Tang K, Grossart HP, Ploug H (2003) Dynamics of microbial communities on marine snow aggregates: colonization, growth, detachment, and grazing mortality of attached bacteria. Appl Environ Microbiol 69:3036-3047 
Koike I, Mukai H, Nojima S (1987) The role of the sea urchin, Tripneustes gratilla (Linnaeus), in decomposition and nutrient cycling in a tropical seagrass bed. Ecol Res 2: $19-29$

Lauzon-Guay JS, Scheibling RE (2007a) Behaviour of sea urchin Strongylocentrotus droebachiensis grazing fronts: food-mediated aggregation and density-dependent facilitation. Mar Ecol Prog Ser 329:191-204

Lauzon-Guay JS, Scheibling RE (2007b) Seasonal variation in movement, aggregation and destructive grazing of the green sea urchin (Strongylocentrotus droebachiensis) in relation to wave action and sea temperature. Mar Biol 151: $2109-2118$

Lawrence JM, Klinger TS (2001) Digestion in sea urchins. In: Lawrence JM (ed) Edible sea urchins: biology and ecology. Elsevier, Amsterdam, p 103-113

Lee BG, Fisher NS (1992) Decomposition and release of elements from zooplankton debris. Mar Ecol Prog Ser 88: $117-128$

Lowry OH, Rosebrough NJ, Farr AL, Randall RJ (1951) Protein measurement with the folin phenol reagent. J Biol Chem 193:265-275

Madin LP (1982) Production, composition, and sedimentation of salp fecal pellets in oceanic waters. Mar Biol 67:39-45

> Mamelona J, Pelletier E (2005) Green urchin as a significant source of fecal particulate organic matter within nearshore benthic ecosystems. J Exp Mar Biol Ecol 314:163-174

Mills SC, Peyrot-Clausade M, Fontaine MF (2000) Ingestion and transformation of algal turf by Echinometra mathaei on Tiahura fringing reef (French Polynesia). J Exp Mar Biol Ecol 254:71-84

Møller EF, Thor P, Nielsen TG (2003) Production of DOC by Calanus finmarchicus, C. glacialis and C. hyperboreus through sloppy feeding and leakage from fecal pellets. Mar Ecol Prog Ser 262:185-191

Newell R (1965) The role of detritus in the nutrition of two marine deposit feeders, the prosobranch Hydrobia ulvae and the bivalve Macoma balthica. Proc Zool Soc Lond 144: $25-45$

Noji TT, Borsheim KY, Rey F, Nortvedt R (1999) Dissolved organic carbon associated with sinking particles can be crucial for estimates of vertical carbon flux. Sarsia 84: 129-135

Paffenhöfer GA, Knowles SC (1979) Ecological implications of fecal pellet size, production, and consumption by copepods. J Mar Res 37:35-49

Peduzzi P, Herndl GJ (1986) Role of bacteria in decomposition of fecal pellets egested by the epiphyte grazing gastropod Gibbula umbilicaris. Mar Biol 92:417-424

Pinnegar JK, Polunin NVC (2006) Planktivorous damselfish support significant nitrogen and phosphorus fluxes to Mediterranean reefs. Mar Biol 148:1089-1099

Pomeroy LR, Deibel D (1980) Aggregation of organic matter by pelagic tunicates. Limnol Oceanogr 25:643-652

Pomeroy LR, Hanson RB, McGillivray PA, Sherr BF, Kirch-

Editorial responsibility: Jonathan Cole,

Millbrook, New York, USA man D, Deibel D (1984) Microbiology and chemistry of fecal products of pelagic tunicates: rates and fates. Bull Mar Sci 35:426-439

Povero P, Misic C, Ossola C, Castellano M, Fabiano M (2003) The trophic role and ecological implications of oval faecal pellets in Terra Nova Bay (Ross Sea). Polar Biol 26: 302-310

Robertson DR (1982) Fish feces as fish food on a Pacific coral reef. Mar Ecol Prog Ser 7:253-265

Robison BH, Bailey TG (1981) Sinking rates and dissolution of midwater fish fecal matter. Mar Biol 65:135-142

Rothans TC, Miller AC (1991) A link between biologically imported particulate organic nutrients and the detritus food web in reef communities. Mar Biol 110:145-150

Roy S, Poulet SA (1990) Laboratory study of the chemical composition of aging copepod fecal material. J Exp Mar Biol Ecol 135:3-18

Scheibling RE, Hatcher BG (2007) The ecology of Strongylocentrotus droebachiensis. In: Lawrence JM (ed) Edible sea urchins: biology and ecology. Elsevier, Amsterdam, p 353-392

- Scheibling RE, Hennigar AW, Balch T (1999) Destructive grazing, epiphytism, and disease: the dynamics of sea urchin kelp interactions in Nova Scotia. Can J Fish Aquat Sci 56:2300-2314

Stevens J (1986) Applied multivariate statistics for the social sciences. Lawrence Erlbaum Associates, Hillsdale, NJ

Taghon GL, Nowell ARM, Jumars PA (1984) Transport and breakdown of fecal pellets: biological and sedimentological consequences. Limnol Oceanogr 29:64-72

> Tang KW, Grossart HP, Yam EM, Jackson GA, Ducklow HW, Kiørboe T (2006) Mesocosm study of particle dynamics and control of particle associated bacteria by flagellate grazing. Mar Ecol Prog Ser 325:15-27

- Thor P, Dam HG, Rogers DR (2003) Fate of organic carbon released from decomposing copepod fecal pellets in relation to bacterial production and ectoenzymatic activity. Aquat Microb Ecol 33:279-288

Turner JT (1979) Microbial attachment to copepod fecal pellets and its possible ecological significance. Trans Am Microsc Soc 98:131-135

Turner JT (2002) Zooplankton fecal pellets, marine snow, and sinking phytoplankton blooms. Aquat Microb Ecol 27: $57-102$

Urban-Rich J (1999) Release of dissolved organic carbon from copepod fecal pellets in the Greenland Sea. J Exp Mar Biol Ecol 232:107-124

Wotton RS, Malmqvist B (2001) Feces in aquatic ecosystems. Bioscience 51:537-544

Yoon WD, Marty JC, Sylvain D, Nival P (1996) Degradation of faecal pellets in Pegea confoederata (Salpidae, Thaliacea) and its implication in the vertical flux of organic matter. J Exp Mar Biol Ecol 203:147-177

Zar JH (1999) Biostatistical analysis, 4th edn. Prentice Hall, Upper Saddle River, NJ

Submitted: February 19, 2009; Accepted: June 11, 2009

Proofs received from author(s): July 12, 2009 